\title{
Dr. Seuss, felicitator
}

\begin{abstract}
Aaron Ahuvia
Abstract: This article uses the life and work of Theodor Geisel (aka Dr. Seuss) to discuss certain aspects of what it means to be a 'felicitator', i.e. a person who brings happiness to others. The focus is particularly on his promotion of creativity and social inclusion, and his critique of materialism.
\end{abstract}

Keywords: happiness, subjective well-being, subjective wellbeing, materialism, social status, fashion, creativity

\section{$80 \cdot \cos$}

If people become the books they read and if 'the child is father to the man,' then Dr. Seuss (Theodor Seuss Geisel) is the most influential author, poet, and artist of modern times.

- John Granger (2004), from his review of Dr. Seuss: American Icon

\section{Introduction}

The obvious hyperbole of Granger's quote (above) notwithstanding, his underlying point that children's book authors potentially influence many lives is certainly sound. ${ }^{1}$ Theodor (Ted) Seuss Geisel (1904-1991), better known as Dr. Seuss, had a long and varied career. But it is as the author and illustrator of some of the most beloved children's books of the twentieth century that he will be long remembered, and, I will argue, through which he became a felicitator par excellence.

A felicitator ${ }^{2}$ is a person or thing which brings happiness to others. As with most good authors, Dr. Seuss was a felicitator in part through the enjoyment people derived directly from his work. But he was a felicitator in a more profound sense as well, because he has helped teach a particular set of values and outlook on life to hundreds of millions of children. Geisel disliked the heavy-handed moralism which was endemic to the children's literature of his day, but many of his works nonetheless taught a moral point of view. Like that of many children's authors, his work emphasized honesty and our responsibility to protect those weaker than ourselves. But somewhat less typically, especially for an author of his generation, his work championed personal creativity while rebuking snobbery, materialism, conformity and

\footnotetext{
${ }^{1}$ This paper focuses in particular on materialism and happiness. In this regard it is worth noting that the ideas children are exposed to through the media have been shown to have a significant influence on their levels of materialism (Bottomley, Nairn, Kasser, Ferguson \& Ormrod 2010).

2 I coined the term "felicitator" in 2010 as part of the work of Project+.
} 
prejudice. It is the values that underlie Seuss's stories, and not just the memorable rhymes and funny illustrations, which gave his work the classic status it has today. And it is these values which form the foundation of my argument that he was a felicitator. Specifically, I argue that his books had a modest but nonetheless real influence on millions of children, encouraging their imaginative creativity and discouraging snobbery, social exclusion and materialism. I also review research showing the positive connection between creativity and happiness and the negative connections between snobbery, social exclusion, materialism on the one hand and happiness on the other. So to the extent that "people become the books they read" (Granger 2004), children raised on Dr. Seuss had improved odds of growing up to be happy adults. ${ }^{3}$

\section{Theodor Seuss Geisel}

As an undergraduate at Dartmouth College (class of 1925), Geisel was editor of the school humor magazine, The Jack-O'-Lantern. He held the editorship until he was forced to resign by the university administration as a penalty for a party in his room that was raided by the police, who, despite Prohibition, found alcohol there. To get around his official banishment from the magazine, Geisel continued to write for The Jack-O'-Lantern using a variety of aliases including Seuss, his middle name and his mother's maiden name. Some years later he appended "Dr." to his pseudonym "as a tongue-in-cheek reference to the doctorate in literature he blew off when he dropped out of (a PhD program at) Oxford" (Schulman 2004, p. 6). "Dr. Seuss" became his primary pseudonym from that time on, although he also published over a dozen books under the name Theo LeSieg (LeSieg is Geisel spelled backwards).

Ted Geisel was 53 years old before his career as a children's author really took off. Years before that, he had achieved minor celebrity status for his work as a humorous advertising copywriter. Geisel never had an ambition to be an ad man, but after he included the brand name Flit in one of his early cartoons, he was asked by Flit insecticide to create an ad campaign. The resulting ads were a huge hit - Fred Allen and Jack Benny referenced the ads in their comedy routines, and there was even a song based on them. Geisel produced the Flit and other advertisements for 17 years, during which he used advertising as an economic base from which to explore other opportunities. He found some success as a humor cartoonist and as a liberal political cartoonist where he advocated US involvement in WWII, prior to Pearl Harbor (see Figure 1 below). Writing and illustrating children's books started out as just another sideline in Geisel's attempt to cobble together a career. He published his first children's book, And to Think That I Saw it All on Mulberry Street in 1937, in part because writing children's literature was one of the permitted side activities in his advertising contract. ${ }^{4}$

After the United States entered World War II Geisel enlisted and served a seven-year stint in the US military, where he scripted training and propaganda films under his commanding officers Frank Capra (the legendary film director) and Jack Jones (the animator who created Bugs Bunny and Daffy Duck). After the army, he tried his hand at Hollywood script writing. Over the course of his work in the military and in Hollywood, he wrote three Academy awardwinning documentaries. But he found working in Hollywood as part of the studio system very

\footnotetext{
3 This quotation comes from John Granger's (2004) online review of Dr Seuss: American Icon. http://www.amazon.com/Dr-Seuss-American-Phillip-Nel/dp/0826414346/ref=cm_cr_pr_orig_subj

${ }_{4}^{4}$ This is sometimes presented as a coincidence, as if the contract had just happened by chance to permit authoring children's books, which led him to this work. But how did that clause find its way into his contract to begin with? It is quite plausible that he had an interest in this occupation and requested that his advertising contract allow him to work in children's literature. If so, this would fit a pattern throughout his life of recasting his past as a series of happenstance serendipitous events, when in fact he played an active role in bringing those events about.
} 
unpleasant. When it came to his creative work Geisel was perfectionistic, uncompromising, and did not, as the expression goes, 'play well with others'. Being a self-employed author suited him much better. So, having determined that he and his wife could live on $\$ 100$ per week, in 1953 he asked his agent, "if I drop everything else (to focus exclusively on writing children's books), do you think I could count on royalties of \$5000 a year?" (Morgan \& Morgan 1995, p. 140). Although he had previously published seven children's books, some of which had been fairly popular, his royalty payments were modest. So his decision to give up his advertising and scriptwriting work was no small economic risk.

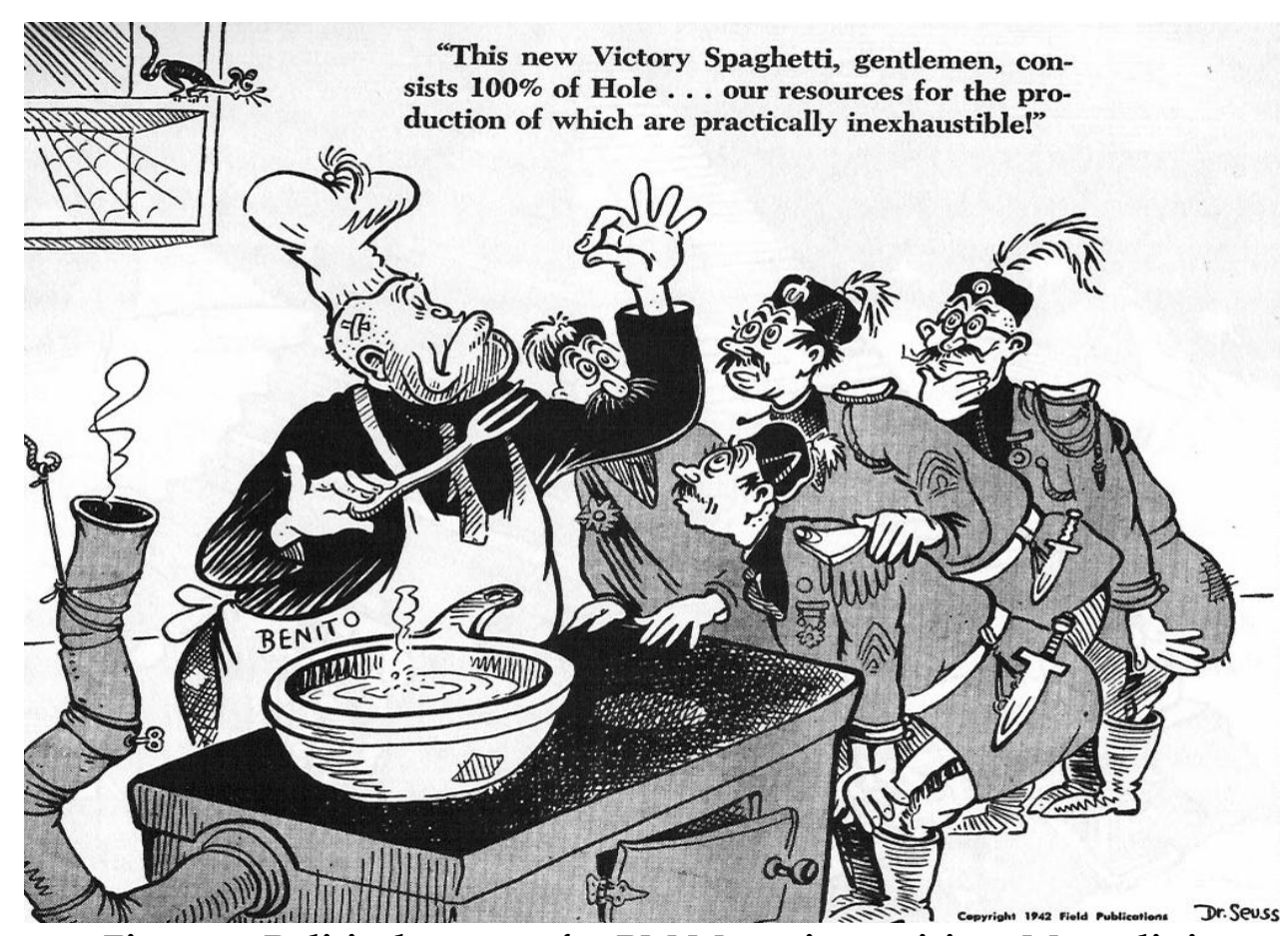

Figure 1: Political cartoon for PM Magazine satirizes Mussolini

There is a saying among product designers, that 'it takes 20 years before a product becomes an overnight success' - so too with Dr. Seuss. In 1957, 20 years after his first children's book, he published The Cat in the Hat and How the Grinch Stole Christmas, both of which were wildly popular and transformed Dr. Seuss into a children's literature superstar. In total, Geisel authored 44 books, which have collectively sold over one half billion copies. ${ }^{5}$

\section{Imagination and creativity}

Dr. Seuss's first book, And to Think That I Saw It All on Mulberry Street (1937) was rejected by as many as $43^{6}$ publishers before a chance meeting on the street between Geisel and an old college friend, who had just entered the publishing business, led to its production. While utterly unremarkable today, what made And to Think That I Saw It All on Mulberry Street a tough sell to publishers in the 1930s was the fact that it took the perspective of a creative child who was frustrated by his father's preference for the dry truth over the child's imaginative stories. Many

\footnotetext{
${ }^{5}$ Some of my personal favorites not mentioned so far include McElligot's Pool, Horton Hears a Who!, Green Eggs and Ham, Yertle the Turtle and Other Stories, The Sneetches and Other Stories, The Lorax, and finally Oh, The Places You'll Go!; which, interestingly, has since become a common gift from parents upon their children's graduation from college.

${ }^{6}$ The number of publishers, like so many other things in Geisel's life, got larger with each retelling and isn't conclusively known. The source of the number 43 used here is Lurie (1990).
} 
publishers saw this empathy for the child's perspective as anti-authority (Lurie 1990). And in a way it was, since our creative imagination allows us to see beyond the existing social structure and towards the possibility of a different and better way of life. Indeed, it has oft been noted that Dr. Seuss's characters "express a kind of freedom from conventional ways of thinking" (Renthal 1962) and in "many of his books there is a strong liberal, even anti-establishment moral" (Lurie 1990, p. 51).

From his first book on, Dr. Seuss was always allied "with the child's free spirit" (Lanes 1971, as cited in Nel 2004, p. 251) as he celebrated "the wildest flights of fantasy" (Lurie 1990, p. 51). Seuss goes so far as to suggest that a child's creativity needs protection from small-minded authority figures, a view formed in part by his experience in his high school art class. As Geisel recounts the story:

Our model that day was a milk bottle containing few scraggly late autumn daisies. I was having a real bad time trying to capture the beauty of this setup and immortalize it with a hunk of charcoal in a sheet of paper. To add to my frustration, my teacher kept fluttering about them giving me hell for turning my drawing board around and working on my picture upside down. "No, Theodor," she said. "Not upside down! There are rules that every artist must abide by. You will never succeed if you break them."7

At the end of the hour Geisel transferred out of the class, and so ended his first and only encounter with formal art education (Morgan \& Morgan 1995). Traces of this experience can be heard in Geisel's warning that if "you don't get imagination as a child, and probably never will [ . . ] because it gets knocked out of you by the time you grow up" ("Logical Insanity of Dr. Seuss" p. 58, as quoted in Nel 2004, p. 123).

Seuss's child characters often modeled a strategy for retaining their imaginative free spirit by keeping it hidden from adults (Lurie 1990). For example, in And to Think That I Saw It All on Mulberry Street, Marco, the child protagonist, uses his imagination to turn a simple horse and buggy into a magnificent parade. But Marco then conceals this fantasy from his father, who had previously admonished him to "stop telling such outlandish tales."

Imaginative and frequently zany characters often play the role of felicitator in Seuss's work, bringing happiness to those around them. As Nel (2004, p. 123) writes:

The Cat in the Hat, Sam-I-am, and the narrator of On Beyond Zebra! are all characters who use the imagination to create possibility... So, instead of remaining secure behind social or linguistic norms, these characters encouraged us to explore what happens when we break the rules. In so doing, Harold Hill brings joy into River City, the Cat brings excitement into a dull suburban home, and Sam-I-Am invites us to taste the unexpected.

Seuss also noted the way imaginative creativity is an intrinsically rewarding activity. For example, while Marco never told his father about his imaginative reverie, the creative process left Marco energized and full of joy:

I swung 'round the corner

And dashed through the gate,

I ran up the steps

And I felt simply GREAT!

\footnotetext{
${ }^{7}$ Morgan and Moran (1995), p. 21.
} 
No one would deny that creative expression can often feel good, but so can any number of activities that are nonetheless in the long run deleterious to one's happiness. Even if one accepts the premise that at least some of those one half billion Dr. Seuss books influenced children to value and participate in imaginative creativity, does this increase in creative behavior make Dr. Seuss a felicitator? What does the scientific research have to say on the subject of imagination, creativity and happiness?

There is a significant body of literature showing that - contrary to the stereotype of the brooding artist - being happy increases creativity (Argyle 2001, Davis 2009, Gasper 2004). Happiness boosts creativity primarily because positive moods increase mental arousal (Filipowitz 2006), and also because happy people are "more relaxed and more open to new experiences; therefore, they can make more diverse associations, generate more ideas as the thoughts flow freely without the restraint" (Pannells \& Claxton 2008, p. 71). Nonetheless, two caveats are in order. First, positive moods help people generate new ideas, but negative moods can actually be more helpful in evaluating the merit of those ideas (Davis 2009). Furthermore, there can be too much of a good thing, and as people reach the very highest possible levels of happiness creativity diminishes (Davis 2009).

Cohen-Meitar, Carmeli and Waldman (2009) provide findings which suggest a virtuous circle may exist for creativity and happiness in the workplace (see Figure 2 below). This study revealed that employees who found their work to be meaningful (i.e. personally important to them in some larger intrinsic sense) identified more strongly with the organizations which employed them, and also felt happier at work. Furthermore, employee happiness was associated with increased productive creativity at work, as assessed by the employees' supervisor. Since supervisors usually convey their evaluation of employees to those employees, it's reasonable to assume that employees whose supervisors believe them to be highly creative and productive should on average come to see themselves as relatively more successful at work. Other research has shown that feeling successful at work is strongly linked to happiness (Warr 1999). Combined, these findings suggest a positive feedback loop whereby employees who experience work as a meaningful and happy activity become more creative in productive ways, which is in turn noted by their supervisors, and thus increases the employees' assessment of their own professional success, which finally produces yet more happiness for those employees.

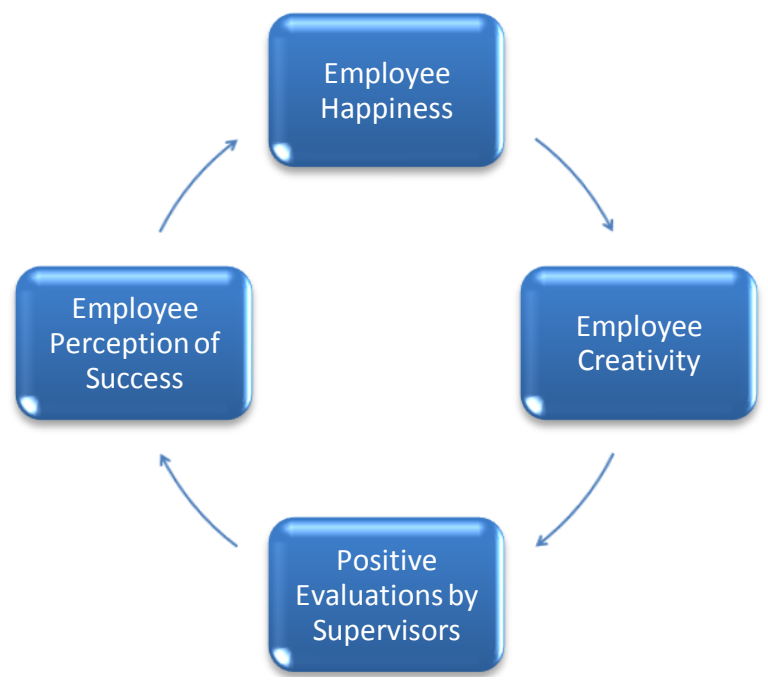

Figure 2: Employee Creativity and Happiness 
In contrast to the robust literature on the effect of happiness on creativity, there are relatively few studies which look at the impact of personal creativity on one's own, or others', happiness. Nonetheless, what data do exist support the claim that encouraging creativity and selfexpression also encourages personal happiness and has positive spillover effects for society at large.

Csikszentmihalyi (1990) documents in detail the role creativity plays in flow and optimal experience. At the other end of the emotional spectrum, Grieves (2009) conducted a controlled experiment with patients suffering from clinical depression, and found that increased creative activity was therapeutic and led to decreased depression.

A recent study by Georgellis, Tsitsainis, and Yin (2009) shows that, across Europe, valuing creativity is positively correlated with happiness. This study analyzed data from the European Social Survey (2002 \& 2004). Respondents were asked how important it was for them to (a) think of new ideas and be creative; (b) be rich and own expensive things; (c) show abilities and be admired; (d) seek respect from others; (e) help people; and (f) follow traditions and customs. The answer most consistently and positively associated with happiness was the importance of thinking of new ideas and being creative.

Creativity is also linked to happiness at the community level. Di Giacinto, Ferrante, and Vistocco found that "access to creative environments appears to have a positive impact on happiness" (2007, p. 1). Specifically, their study used Florida's creativity index (Florida \& Tinaglia 2005) to assess the creative output, embrace of diversity, and tolerance for individual eccentricity, for various geographic regions in Italy. After controlling for income and other demographic factors, they found a positive correlation between a community's creativity index, and the happiness of the people who live there. Shifting our focus from geographic communities to organizations, similar results were obtained by Rasulzada and Dackert (2009), who found that fostering a creative organizational climate leads to higher levels of perceived creativity and innovation by employees, which in turn leads to greater happiness, enthusiasm and optimism amongst those employees.

\section{Conspicuous consumption, materialism and social exclusion}

As a child growing up in Springfield Massachusetts during World War I, Ted Geisel was pelted with coal by other schoolchildren because of his German heritage. He recalled in an interview how, prior to WWI, his German-American relatives "did get into some clubs like the Elks, and they took us kids to Elks clam bakes where we ate lobsters and Quahog clams and corn-on-thecob and our fathers drank beer until our mothers made them stop and we all came home on the trolley car singing and wildly happy" (Morgan \& Morgan 1995, p. 18). But the good relations between Geisel's childhood German-American ethnic community and the majority population of his home town ended when America entered WWI. Later, as a freshman at Dartmouth he would have a similar experience of social exclusion as he was not invited to join any of the fraternities, this time not because of his German heritage but because of a false rumor that he was Jewish. Thus, in a plot twist worthy of one of his own books, Geisel, a third-generation American and Christian from birth, managed to suffer both from anti-German bigotry and antiSemitism. In interviews Geisel would cite these experiences when explaining the origins of his story The Sneetches, a parable about the hoity-toity Star-Belly Sneetches and their hoi polloi brethren the Plain-Belly Sneetches. And it's easy to hear Geisel's experience of being excluded from the clam bakes as a child and later from Dartmouth fraternities in verses from The Sneetches (1961) like:

But, because they had stars, all the Star-Belly Sneetches 
Would brag, "We're the best kind of Sneetch on the beaches."

With their snoots in the air, they would sniff and they'd snort

"We'll have nothing to do with the Plain-Belly sort!"

And whenever they met some, when they were out walking,

They'd hike on past them without even talking...

When the Star-Belly Sneetches had frankfurter roasts

Or picnics or parties or marshmallow toasts,

They never invited the Plain-Belly Sneetches.

They left them out cold, in the dark of the beaches.

They kept them away. Never let them come near.

And that's how they treated them year after year.

The Sneetches began as a short illustrated poem published in Redbook magazine in 1953, which satirized racial, religious or ethnic prejudice and animosity. But when Dr. Seuss expanded the 1953 poem to create the illustrated story The Sneetches (1961), the topic also shifted toward classbased prejudice and the role of luxury goods as status markers. The 1953 and 1961 versions start out much the same, but the 1961 version departs from the earlier poem when a pitchman named Sylvester McMonkey McBean arrives on the scene. McBean unpacks an enormous contraption - a Star-On Machine - which prints stars on the Plain-Belly's bellies to make them indistinguishable from Star-Belly Sneetches (see Figure 3 below). McBean sells trips through the Star-On Machine to the Plain-Belly Sneetches. The idea that one could buy an upgrade in one's social status doesn't fit well with a satire of bigotry based on race or religion; but it fits quite well as a metaphor for class-based bigotry and the role of conspicuous consumption in facilitating class snobbery.

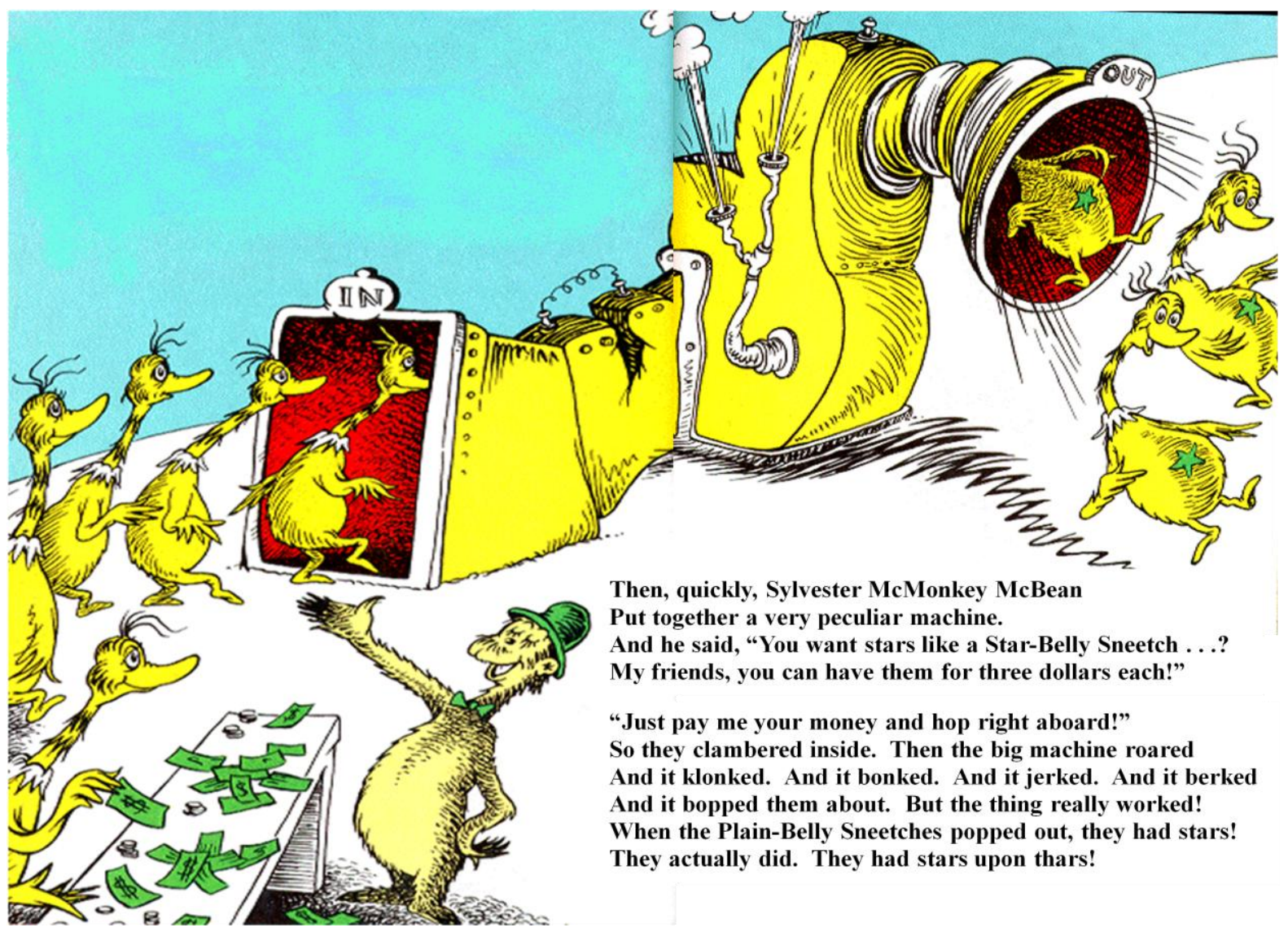

Figure 3: McBean and his Star-On Machine 
The Sneetches presents a succinct illustration of the 'trickle-down' (Simmel 1904, Veblen 1899), a.k.a. 'chase and flight' (McCracken 1985) theory of fashion, according to which fashion items such as designer brands are used by elites to mark their superior status and differentiate them from the rest of us. These same fashion brands then become attractive to wannabe elites who seek to emulate the fashion leaders and perhaps even join the elite group. Since the whole value of the status brand to the elites was that it distinguished them from the non-elites, once the brand becomes too popular with non-elites it loses its value to the original elite group. As Dr. Seuss would put it, "from then on, as you've probably guessed. Things really got into a horrible mess" (1961, p. 19). The elites drop the now passé status symbol, and opt for a new brand or style. Eventually, the non-elites catch on to the fact that the elites have abandoned their former status marker, and the fashion cycle keeps relentlessly chugging along.

Lest the role of fashion in this whole process of elitism and exclusion be missed by the reader, Dr. Seuss spells it out quite explicitly. Once the Plain-Belly Sneetches acquire stars, the Star-Belly Sneetches become furious that the riffraff now have their status markers. McBean, it turns out, also has a solution to the Star-Belly's status problem. "Belly stars are no longer in style" says McBean "what you need is a trip through my Star-Off Machine"! As the book continues, McBean whips both groups into a fashion-fueled status symbol-buying frenzy:
All the rest of that day, on those wild screaming beaches,
The Fix-it-Up Chappie kept fixing up Sneetches.
Off again! On again!
In again! Out again!
Through the machines they raced round and about again,
Changing their stars every minute or two.
They kept paying money. They kept running through.

In the story, this continues until "every last cent of their money's been spent." For many, this fate is hardly fictitious, as conspicuous status consumption has been linked to problematic consumer debt (Lea, Webley, \& Walker 1995), and the compulsive consumption which can lead to that debt (D'Astous, Maltais \& Roberge 1990).

Since The Sneetches was published several developments have dramatically expanded the percentage of the population "running round and round-bout again" in this status game (Patrick \& Hagtvedt 2009). First, the development of designer labels made it easier for nonelites to play the game. Previously, in order to play one needed to devote enough time and energy to developing a connoisseur's eye for fashion and luxury goods, that one could distinguish what was hot from what was not, based on the aesthetic properties of the object in question. Visible designer labels have made the process of identifying status goods much simpler and hence made the status game accessible to a much larger audience. This change corresponded to the development of what people in the luxury goods business call 'accessible luxuries.' These are products like a $\$ 150$ Gucci keychain, which while much more expensive than comparable non-designer products, are still priced low enough to be affordable to a highly motivated middle-class consumer. The combination of visible labels and accessibly priced products has led to the spread of this status game to the mass public.

The image of the Sneetches getting stars popped onto and off of their bodies is readily translatable into designer logos on clothing. But this competitive consumption status system extends far beyond designer clothes. The car one drives, beverages one drinks (from wine and liquor, the beverage status game has spread to beer, coffee, tea and even bottled water), the home one lives in, golf clubs (both the kind one plays with and the kind one plays at), etc., are all common consumption domains where this status competition takes place. Nor are tangible 
products inherently more status oriented than services or experiences. For example, the ad for vacation travel is based on the premise that the resort others haven't been to yet (and are hence dreaming about) allows you to score more status points than does going to a resort which is more common (note the double meaning of 'common' as frequent but therefore inherently not elite).

Seeing this status competition as a 'game' is a useful metaphor. In the Sneetches story, the game was primarily a team sport (the Plain-Belly vs the Star-Belly), but in real life the game has qualities both of a team and of an individual competition. It is perhaps unsurprising that if given their druthers, the elites wouldn't want to even play in the same league as the masses and so they don't. The fashion-based status symbol game has developed what I call three 'leagues' - which I will dub the ' $C$ ' league, ' $B$ ' league, and 'A' league - hierarchically organized of course! The $C$ league is the most widely accessible and therefore least elite. It is a hallmark of low sophistication consumers who play in the $C$ league that, by and large, they do not even know that the other two leagues exist. $C$ league players compete by purchasing major designer label products with visible designer logos (Han, Nunes \& Drèze 2010). The bigger the product and the bigger the logo, the more it costs and hence the more 'points' a consumer scores for displaying it. Therefore, winning in the $C$ league is largely just a function of how much money one spends. Or at least, this used to be the case before 'cheating' (buying counterfeits) became an easily accessible option. The FBI calls counterfeiting "the crime of the $21^{\text {st }}$ century" (Chow 2003, p. 9) because counterfeiting designer luxury goods is a business of staggering proportions (Gistri, Romani, Pace \& Ahuvia 2010).

Counterfeiting is less of an issue in the B league, and hardly occurs in the A league at all. This is because counterfeiters rarely find it profitable to create imitation versions of the products favored in these higher leagues. The B league competes mainly through the use of the same designer brands purchased by participants in the $C$ league, but B leaguers prefer products within those brands which have less conspicuous or even non-visible designer logos (Han, Nunes \& Drèze 2010). Thus success in this league requires more knowledge of the designer product lines and of fashion trends, than does success in the $C$ league. Participants in the $B$ league generally have higher incomes and are more broadly immersed in the world of fashion than are $\mathrm{C}$ league competitors.

The A league is a small group of generally quite wealthy people who live in culturally elite cities such as New York, London, Milan or Paris; and fancy themselves as not only the economic elite but the cultural avant-garde. They typically reject the well-known designer labels altogether, and prefer lesser known small-production designers. If brands move between leagues, the typical pattern is for them to start in the A league and then gradually move down market, where the possibility of much greater sales volume allows for higher profits. In some cases though, such as Coach handbags, brands may start out as mass market brands and then move up into the B league.

\section{Happiness, Money and Status Games}

One might reasonably ask, what's wrong with playing this particular game? All competitive games have winners and losers; that's part of what makes them fun. Couldn't one argue that 'this is a fun game and fun games make us happy'? Certainly many postmodernist 'liberationist' thinkers would argue along those lines (Campbell 1991, p. 62-63). Furthermore, people need to form a coherent sense of identity to be happy (Ahuvia 2005, Burroughs \& Rindfleisch 2002). The products we choose are an important part of this identity creation 
process (Ahuvia 2005, Ahuvia et al. 2009, Belk 1988). So, as Twitchell (1999) argues, shouldn't we just get over it and let people enjoy their status games?

It would be foolish to deny the importance of creating a coherent sense of personal identity, or to deny that shopping for, buying and using all sorts of stuff can be fun. But research shows that there are different ways of relating to money and consumption, different ways of creating a sense of identity, and different ways of having fun, some of which produce longer lasting happiness than others. And unfortunately for avid players of the remarkably popular status game satirized in The Sneetches, the data on happiness recommend other hobbies.

Nonetheless, before exploring the research in greater detail, I should caution against two common prejudices that can lead people to draw incorrect inferences. The first of these prejudices stems from gender stereotypes. The word 'fashion' refers specifically to clothing and accessories, but it also refers to a much wider phenomenon where all kinds of things go in and out of style; e.g. cars, furniture, music, food, architecture, the arts, political beliefs, academic theories, investment strategies. Because designer clothing and accessories provide such handy illustrative examples of status-driven fashions, many people incorrectly equate conspicuous consumption with the purchase of these particular goods. And since designer brands are more popular with women than with men (although interest by men is increasing), this misleads some people to think of conspicuous consumption as a particularly female problem. But there are plenty of publicly visible consumer goods, such as cars, through which even the least metrosexual male can conspicuously display his status.

The second prejudice is intellectual and/or counter-cultural snobbery. Although intellectuals love to poke fun at the status games where money is used to score points, wealth is just one 'field' on which this game is played (Bourdieu 1984). Academics score points in the 'I'm smarter than you' competition through their publications. Cultural elites score points in the 'who's more sophisticated' contest through having 'better' taste in food, wine, art, music, etc. ${ }^{8}$ Tattoos are perhaps the most direct analogy to the belly stars, and tattoos were widely used to score points in the 'I'm cooler and more counter-culture than you are' competition between about 1990 - 2005, when they finally became so mainstream that they went out of style. Most of this article will focus on luxury goods as conventional status symbols in part because they fit with the Sneetches story, and in part because they are by far the most widely researched. But I would stress that many of the psychological problems associated with materialistic status consumption may well apply to these other status games as well.

\subsection{Sneetchie behavior is an aspect of materialism}

As discussed above, it was easy for Dr. Seuss to transform his story, originally about racism and anti-Semitism, into a story about the folly of fashion, conspicuous consumption and materialism. This is because these phenomena are more closely linked than one might first think. When a privileged status is assigned (or denied) based on groups one is born into, we call this racism, etc.; but when a similar status claim is made through the things money can buy, we call it materialism. In fact, Roets, Hiel and Cornelis (2006) have found that materialism is one of the primary psychological predictors of racist attitudes, thus suggesting that there is an underlying psychological connection between these two mechanisms for assigning ingroups and outgroups.

In The Sneetches, Dr. Seuss focuses on how materialism, through the purchase of status symbols, is used to shape relationships between people (or Sneetches, as the case may be). In

\footnotetext{
${ }^{8}$ See the literature on 'cultural capital' for much more on this topic.
} 
particular, the materialistic use of status symbols is embedded in competitive and antagonistic social relationships. Research confirms this connection, finding that materialistic people tend to view their social relationships in competitive and hierarchical ways (Christopher et al. 2005). For example, materialistic people are more likely to compare their incomes to their co-workers' (Clark \& Senik 2010), value power over others more than a benevolent concern for others (Richins 2004), and value purchases that allow them to gain social status rather than those purchases that facilitate warm relationships with others (Richins 1994, 2004). As Kasser (2008, p. 176) put it, an orientation towards "materialistic goals is associated with being less agreeable and empathic, and with being more Machiavellian, socially dominant, and competitive (vs. cooperative) in social dilemma games." Claxton, Murray and Janda (1995) found that these patterns applied in one's home life as well, as materialists were disproportionately likely to have 'cool' rather than 'warm' marital relationships (see also Kasser \& Ryan 2001). Similarly, Burroughs and Rindfleisch (2002, p. 365) conclude that materialists seek "mastery and control over others. Thus, materialistic individuals appear to be not only hedonistic pleasure seekers but also power-hungry control seekers." In sum, materialism is often less about a person's excessive focus on material objects, than it is about using money and the things it can buy to gain power over, or win status competitions against, other people. Since having warm and positive social relationships has been shown to be such an important predictor of happiness (Myers 1999), this competitive interpersonal orientation may be one reason why materialism is so frequently associated with unhappiness.

\subsection{Materialism is linked to unhappiness}

In The Sneetches, Dr. Seuss's primary criticism of the elite Star Bellies is that their snobbery and exclusionary social practices caused harm to the Plain Bellies. In this respect, his book understates quite significantly the problems associated with the behavior Dr. Seuss satirizes. It is not just that the Plain Belly Sneetches are harmed because they can't go to the Star Belly's frankfurter roasts. Rather, the socially competitive frame of mind that underlies why the Sneetches "kept paying their money" and "kept running through" McBean's Star On and Star Off machines, is itself the source of unhappiness and other psychological problems. These problems would afflict the Star Bellies and the Plain Bellies alike.

One of the first scientific scales to measure materialism came from Belk (1985), who saw materialism as consisting of three parts: envy, non-generosity, and possessiveness. Using these measures, highly materialistic people were shown to be less happy in life, and less prone to helping others, when compared with less materialistic people (Belk 1985). Later, Richins and Dawson (1992) developed a materialism scale which defined materialists as people who (a) believe their success and the success of others can be judged based on a person's possessions, (b) that possessions are needed for happiness, and (c) for whom possessions play a central role in their life. Although Richins and Dawson's scale conceptualizes materialism somewhat differently from Belk (1985), materialists have fared no better in research using this scale. Roberts and Clement (2007) found that when materialism was measured in this way, it was associated with lower overall life satisfaction as well as lower satisfaction with family, friends, self, place of residence, health, fun and enjoyment, one's financial situation, and one's job. Similar findings are quite common (e.g. Nickerson et al. 2003, Ryan \& Dziurawiec 2001, Swinyard et al. 2001, Wright \& Larsen 1993).

The third major theory of materialism comes from Kasser (Kasser 2002; Kasser et al. 2002, c.f. Emmons 1996, Stutzer 2004), and is an extension of self-determination theory. Kasser sees materialism as a particular instance of a larger personal value system which prioritizes 
'extrinsic' over 'intrinsic' life goals. Extrinsic goals include financial success, attractive appearance, and social popularity. These goals are called 'extrinsic' because they "focus on external rewards, praise, and the evaluations of others" (Sheldon \& Kasser 2008, p. 37). On the other hand, intrinsic goals include the desires for self-acceptance and personal growth, affiliation with others, and making a contribution to the larger community. These pursuits "are typically inherently rewarding and...tend to satisfy innate psychological needs such as autonomy, competence, and relatedness" (Sheldon \& Kasser 2008, p. 37). This theory of materialism links the desire for wealth and conspicuous consumption to the psychologicallyrelated goals of physical attractiveness and social prestige. The interconnections between these extrinsic goals can also be seen in Geisel's creation of The Sneetches, in which social prestige is linked both to the materialistic purchase of status goods, and, through his earlier cosmetics advertisement, to the fashion and beauty industries.

Self-determination theory sees lasting happiness as dependent on prioritizing intrinsic over extrinsic life goals. This theory may be most easily understood through an analogy to what I call 'psychological nutrition.' In this view, the mind has certain 'psychological nutrition' needs, and intrinsic goals are those goals which, when met, fulfil these psychological nutrition requirements. Lasting happiness, in this view, is not the result of any particular pleasant experience but rather an outcome of psychological health. Extrinsic goals such as gaining social prestige through conspicuous consumption are the equivalent of mental desserts - attractive and momentarily pleasing, but lacking in psychological nutrition. Obtaining these mental desserts does not promote psychological health and hence does not create long-term happiness. In fairness to desserts, whether chocolate or metaphoric in nature, they can be fun and are dependably pleasurable. Desserts aren't inherently bad, but if they play too large a role in one's life, that can cause real problems. In the case of meeting one's psychological needs, an excessive emphasis on extrinsic goals (psychological desserts) has been empirically associated with "a host of maladies including anxiety, depression, neurotic physical symptoms, unpleasant emotions, drug abuse, alcohol abuse, behavioral disorders, lower levels of self-actualization, less vitality, less life satisfaction and fewer pleasant emotions" (Ahuvia \& Izberk-Bilgin forthcoming). Finally, as if things weren't already looking bad enough for highly materialistic people, it turns out they don't even enjoy their desserts as much as less materialistic people do. That is to say, as compared to people who are low in materialism, high materialists are less satisfied with the products they own in potentially status-signaling product categories, and experience more guilt from splurge purchases (Wang \& Wallendorf 2006).

Self-determination theory is quite different from the typical models of consumer decisionmaking which assume people maximize their self-interest over the long run. These models hold that what makes a goal attractive is the fact that achieving that goal maximizes a person's longterm wellbeing. In contrast, self-determination theory holds that a goal can be highly attractive and motivating, and yet achieving that goal would not provide long-term psychological wellbeing, just as attractive foods don't always provide long-term physical wellbeing. Furthermore, in self-determination theory people rarely learn from this mistake and repeatedly chase after shiny extrinsic goals even though past achievements in these areas have not produced lasting happiness. Puzzling as this failure to learn from experience may sound, it is now a well documented aspect of human decision-making that we consistently mis-estimate how much lasting happiness or unhappiness future events in our lives will bring us (Wilson \& Gilbert 2003). And perhaps even more bizarrely, we seem to have a limitless appetite for repeating these mistakes (Ahuvia 2008). 


\subsection{Is materialism always linked to unhappiness, and why?}

There is quite compelling evidence from a very large number of studies conducted with different populations around the world that materialism in general, and status consumption in particular, are usually linked with unhappiness and a range of other problems. However, there is still legitimate debate based on conflicting evidence as to whether there are important exceptions to this general rule. And these possible exceptions are based on reasons materialism would, or would not, be linked to unhappiness.

Although high income aspirations (i.e. wanting more money) are certainly an aspect of materialism, and have been strongly linked to unhappiness (Johnson \& Krueger 2006, Stutzer 2004), these statements are generalizations which have been shown not to hold true in every case. Desiring more money so as to pursue extrinsic socially competitive goals (e.g. one's next trip through the Star On machine) is quite deleterious to happiness. But wanting money to pursue more prosocial intrinsic goals (e.g. supporting a social cause) or even to fulfill much more neutral personal responsibilities (e.g. saving for retirement) have been found to be unrelated to happiness (Carver \& Baird 1998, Srivastava, Locke \& Bartol 2001).

One of the reasons materialism may be associated with unhappiness is that it leads people to compare their financial status to that of others. The more prone people are to make these financial comparisons, the less happy they tend to be, in part because people tend disproportionately to compare themselves to others who have more than they do (Clark \& Senik 2010). Interestingly, even upwards economic comparisons need not always lead to unhappiness. In some cases, people can be inspired by the successes of others, so seeing others who have been highly successful can lead to a sense of hope and optimism about one's own future. But these positive responses to others' good fortune are, unfortunately, generally outweighed by negative, more competitive responses (Clark \& Senik 2010). In any case, materialism has been shown to exacerbate the negative consequences of upward social comparison (Carver \& Baird 1998). Lyubomirsky (2001, p. 242-243) finds the type of socially competitive orientation typical of materialists to be at the heart of what makes for an unhappy existence:

Our research paints a portrait of unhappy individuals who are deflated rather than delighted about their peers' accomplishments and triumphs and are relieved rather than disappointed or sympathetic in the face of their colleagues' and acquaintances' failures and undoings... One striking finding was that unhappy students reported feeling happier and more self-confident when they had received a poor evaluation (but heard their peer receive an even worse one) than when they had received an excellent evaluation (but heard their peer receive an even better one). Happy students, by contrast, did not show this pattern of sensitive responding to comparisons with peers.

Nonetheless, it still follows that the richer you are the more likely you are to feel good about the economic comparisons you make. And indeed, some studies have found that materialism is not associated with unhappiness among very high income individuals (La Barbera \& Gerhan 1997, Nickerson et al. 2003). However, other studies have found positive correlations between materialism and unhappiness even among affluent individuals (Stutzer 2004). These conflicting findings have yet to be reconciled.

Materialism has also been shown to create unhappiness because materialistic aspirations can conflict with other more community-focused aspirations based on religious and/or family values, thus causing psychological stress. However, among people devoid of family values or 
concern for their community, materialistic values don't cause internal psychological tension and are hence not associated with unhappiness (Burroughs \& Rindfleisch 2002). While this may be good news for those materialists freed from a troubled conscience by having no conscience, it hardly represents a recommendable strategy for achieving happiness on a societal scale.

\section{Conclusion}

This paper has made the argument for Dr. Seuss as a felicitator. Beyond the obvious pleasure his books brought to children and parents alike, his work championed the importance of imagination, creativity, and not just tolerance, but inclusion and the enthusiastic appreciation of difference. While this paper has explored some of his criticisms of consumer society, it should be noted that in his life and work he was a 'flaming moderate' on these issues. In The Grinch Who Stole Christmas, he attacked the way consumption in a commercialized Christmas can supplant the more nourishing and nurturing pleasures he remembered from his youth. But in the end of the story, once the Grinch sees the deeper values and experiences underlying the holiday, Christmas goes ahead with both singing and gifts. In The Lorax Dr. Seuss sounded an alarm about the ecologically destructive effects some forms of commercial production can have. But Seuss loved creativity, and he knew that creativity often involved creating things. So his books also contained fabulous cars, colorful costumes and splendid palaces. Yes, he pointed out the folly of the Sneetches, but it was the fact that the Plain-Bellies weren't invited to the frankfurter roasts, not the fact that people like frankfurters, that he inveighed against. Ever the optimist, after "every last cent of their money's been spent" on status symbols, Dr. Seuss has the now-destitute Sneetches finally see the folly of their ways.

That the Sneetches got really quite smart on that day,

The day they decided that Sneetches are Sneetches

And no kind of Sneetch is the best on the beaches.

That day, all the Sneetches forgot about stars

And whether they had one, or not, upon thars.

Surely, this is felicitous advice for us all.

\section{Author}

Aaron Ahuvia

University of Michigan - Dearborn

ahuvia@umich.edu

Publishing Timeline

Received 5 February 2011

Accepted 19 May 2011

Published 20 July 2011

\section{References}

Ahuvia, A. C. (2005) 'Beyond the Extended Self: Loved Objects and Consumers' Identity Narratives', Journal of Consumer Research 32(1): 171-184. http://dx.doi.org/10.1086/429607

Ahuvia, A. C. (2008) ‘If Money Doesn't Make Us Happy, Why Do We Act As If It Does?' Journal of Economic Psychology 29(4): 491-507.

Ahuvia, A. C. and E. Izberk-Bilgin (forthcoming) 'Wellbeing in Consumer Societies', in Nic Marks and Sam Thompson, eds., the Oxford Handbook of Happiness. New York: Oxford University Press. 
Ahuvia, A. C., R. Batra, and R. Bagozzi (2009) 'Love, Desire and Identity: A Conditional Integration Theory of the Love of Things', in Deborah J. MacInnis; C. Whan Park; Joseph R. Priester, eds., The Handbook of Brand Relationships. New York: M. E. Sharpe, 342-357.

Argyle, M. (2001) The Psychology of Happiness. New York: Routledge.

Belk, R. W. (1988) 'Possessions and the Extended Self', Journal of Consumer Research 15 (2): 139-168. http://dx.doi.org/10.1086/209154

Belk, R. W. (1985) 'Materialism: Trait Aspects of Living in the Material World', Journal of Consumer Research 12: 265-280. http://dx.doi.org/10.1086/208515

Bottomley, P. A., A. Nairn, T. Kasser, Y. L. Ferguson, and J. Ormrod (2010) 'Measuring Childhood Materialism: Refining and Validating Schor's Consumer Involvement Scale,' Psychology and Marketing 27(7): 717-739. http://dx.doi.org/10.1002/mar.20353

Bourdieu, P. (1984) Distinction: A Social Critique of the Judgement of Taste, Cambridge, MA: Harvard University Press.

Burroughs, J. E. and A. Rindfleisch (2002) 'Materialism and Well-Being: A Conflicting Values Perspective', Journal of Consumer Research 29: 348-370. http://dx.doi.org/10.1086/344429

Campbell, C. (1991) 'Consumption: The New Wave of Research in the Humanities and Social Sciences', Journal of Social Behavior and Personality 6: 403-414.

Carver, C. S. and E. Baird (1998) 'The American Dream Revisited: Is It What You Want or Why You Want It That Matters?' Psychological Science 9: 289-292. http://dx.doi.org/10.1111/1467-9280.00057

Chow, D. (2003) 'Investigating the counterfeit nightmare Procter \& Gamble and Oki Data count the costs', Strategic Direction 19(3): 9-12. http://dx.doi.org/10.1108/02580540310794372

Christopher, A. N., R. D. Morgan, P. Marek, M. Keller, and K. Drummond (2005) 'Materialism and selfpresentational styles', Personality and Individual Differences 38:137-149. http://dx.doi.org/10.1016/j.paid.2004.03.015

Clark, A. E., and Senik, C. (2010) 'Who Compares to Whom? The Anatomy of Income Comparisons in Europe', The Economic Journal 120(544): 573. http://dx.doi.org/10.1111/j.1468-0297.2010.02359.x

Claxton, R. P., J. Murray, and S. Janda (1995) 'Spouses' Materialism: Effects of Parenthood Status, Personality Type, and Sex', Journal of Consumer Policy 18: 267-291. http://dx.doi.org/10.1007/BF01016514

Cohen-Meitar, R., A. Carmeli, and D. A.Waldman (2009) 'Linking Meaningfulness in the Workplace to Employee Creativity: The Intervening Role of Organizational Identification and Positive Psychological Experiences', Creativity Research Journal 21(4): 361.

Csikszentmihalyi, M. (1990) Creativity: Flow and the Psychology of Discovery and Invention New York: HarperCollins.

D'Astous, A., J. Maltais, and C. Roberge (1990) ‘Compulsive Buying Tendencies of Adolescent Consumers', in M. Goldberg, G. Corn, \& R. Pollay, eds., Advances in Consumer Research, Volume 17. Provo, UT: Association for Consumer Research, 306-312.

Davis, M. A. (2009) 'Understanding the relationship between mood and creativity: A meta-analysis', Organizational Behavior and Human Decision Processes 108(1): 25-38.

http://dx.doi.org/10.1016/j.obhdp.2008.04.001

Di Giacinto, M., F. Ferrante, and D.Vistocco (2007) Creativity and Happiness. Presented at the International Conference, Policy for Happiness, Siena, Certosa di Pontignano, 14-17 June, 2007.

Emmons, R.A. (1996) 'Striving and Feeling: Personal Goals and Subjective Well-Being', in Peter M. Gollwitzer and John A. Bargh, eds., The Psychology of Action: Linking Cognition and Motivation to Behavior. New York: Guilford Publications, 313-337.

Filipowitz, A. (2006) 'From positive affect to creativity: The surprising role of surprise', Creativity Research Journal 18: 141-152.

Florida R. and I. Tinaglia (2005) L'Italia nell'era creativa, Creativitycitygroup. Available from: http://www.creativitygroupeurope.com/

Gasper, K (2004) 'Permission to seek freely? The effect of happy and sad moods on generating old and new ideas. Creativity Research Journal 16: 215-229. 
Georgellis, Y., N. Tsitsianis, and Y. Yin (2009) 'Personal Values as Mitigating Factors in the Link Between Income and Life Satisfaction: Evidence from the European Social Survey', Social Indicators Research 91(3): 329-344. doi:10.1007/s11205-008-9344-2. http://dx.doi.org/10.1007/s11205-008-9344-2

Gistri, G., S. Romani, S. Pace, and A. Ahuvia (2010) 'What Is the Harm in Fake Luxury Brands? Moving beyond the Conventional Wisdom', Working paper.

Granger, John (2004), from his review Dr. Seuss: American Icon. http://www.amazon.com/Dr-SeussAmerican-Philip-Nel/dp/0826417086/ref=sr 1 2?ie=UTF8\&s=books\&qid=1274978326\&sr=1-2

Grieves, J. (2009) Depression symptom changes as a function of increased creative behavior over a twoweek recording period. PhD dissertation. The University of North Dakota, United States.

Han, Y. J., J. C. Nunes, and X. Drèze (2010) 'Signaling Status with Luxury Goods: The Role of Brand Prominence', Journal of Marketing 74: 15-30. http://dx.doi.org/10.1509/jmkg.74.4.15

Johnson, W. and R. F. Krueger (2006) 'How Money Buys Happiness: Genetic and Environmental Processes Linking Finances and Life Satisfaction', Journal of Personality and Social Psychology 90(4): 680-691. http://dx.doi.org/10.1037/0022-3514.90.4.680

Kasser, T., and R. M. Ryan (2001) Be Careful What You Wish For: Optimal Functioning and the Relative Attainment of Intrinsic and Extrinsic Goals, in P. Schmuck \& K. M. Sheldon, eds., Life Goals and Wellbeing: Towards a Positive Psychology of Human Striving. Lengerich, Germany: Pabst Science Publishers.

Kasser, Tim (2002) The High Price of Materialism, Boston, MA: MIT Press.

Kasser, Tim (2008) 'Pain and Insecurity, Love and Money', Psychological Inquiry: An International Journal for the Advancement of Psychological Theory 19: 174-178.

Kasser, T., R. M. Ryan, C. E. Couchman, and K. M. Sheldon (2002) 'Materialistic Values: Their Causes and Consequences', in Kasser, T., \& Kanner, A., eds., Psychology and the Culture of Consumption. American Psychological Association Press.

La Barbera, P. A. and Z. Gurhan (1997) 'The Role of Materialism, Religiosity, and Demographics in Subjective Well-Being', Psychology \& Marketing 14: 71-97. http://dx.doi.org/10.1002/(SICI)15206793(199701)14:1\%3c71::AID-MAR5\%3e3.0.CO;2-L

Lanes, S. G. (1971) 'Seuss for the Goose Is Seuss for the Gander', in Down the Rabbit Hole: Realism and Misadventures in the Realm of Children's Literature, New York: Atheneum: 79-89.

Lea, S. E.G., P. Webley, and C.M. Walker (1995) 'Psychological Factors in Consumer Debt: Money Management, Economic Socialization, and Credit Use', Journal of Economic Psychology 16: 681-701. http://dx.doi.org/10.1016/0167-4870(95)00013-4

Lurie, A. (1990) 'The Cabinet of Dr. Seuss'. The New York Review of Books, 37(20). Available from: http://www.nybooks.com/articles/archives/1990/dec/20/the-cabinet-of-dr-seuss/

Lyubomirsky, S. (2001) ‘Why Are Some People Happier Than Others? The Role of Cognitive and Motivational Processes in Well-Being', American Psychologist 56 (3): 239-249.

http://dx.doi.org/10.1037/0003-066X.56.3.239

McCracken, G. D. (1985) 'The Trickle-Down Theory Rehabilitated', in Michael R. Solomon, ed., The Psychology of Fashion. Lexington, MA: Lexington Books, 39-54.

Morgan, J., and N. Morgan (1995) Dr. Seuss \& Mr. Geisel: a biography. New York: Random House.

Myers, D. G. (1999) Close Relationships and Quality of Life, in D. Kahneman, E. Diener, \& N. Schwarz, eds., Well-Being: The Foundations of Hedonic Psychology. New York: Russell Sage Foundation, 353-373.

Nel, P. (2004) Dr. Seuss: American icon. New York: Continuum.

Nickerson, C., N. Schwarz, E. Diener and D. Kahneman (2003) 'Zeroing in on the dark side of the American Dream: A closer look at the negative consequences of the goal for financial success,' Psychological Science 14: 531-536. http://dx.doi.org/10.1046/j.0956-7976.2003.psci_1461.x

Pannells, T., and A. Claxton (2008) 'Happiness, Creative Ideation, and Locus of Control', Creativity Research Journal, 20:67.

Patrick, V. M., and H. Hagtvedt (2009) 'Luxury Branding', in D. J. MacInnis, C. W. Park, \& J. R. Priester, eds., The Handbook of Brand Relationships. NY: Society for Consumer Psychology, 267-280.

Rasulzada, F., and I. Dackert (2009) 'Organizational Creativity and Innovation in Relation to Psychological Well-Being and Organizational Factors', Creativity Research Journal, 21(2): 191.

Renthal, H. (1962) '25 Years of Working Wonder with Words', Chicago Tribune 11: 37-39. 
Richins, M. (2004) 'The Material Values Scale: Measurement Properties and Development of a Short Form', Journal of Consumer Research 31(1): 209-219. http://dx.doi.org/10.1086/383436

Richins, M. L. (1994) 'Special Possessions and the Expression of Material Values', Journal of Consumer Research 21: 522-533. http://dx.doi.org/10.1086/209415

Richins, M. L. and S. Dawson (1992) 'A Consumer Values Orientation for Materialism and Its Measurement: Scale Development and Validation', Journal of Consumer Research 19: 303-316. http://dx.doi.org/10.1086/209304

Roberts, J., and A. Clement (2007) 'Materialism and Satisfaction with Over-All Quality Of Life and Eight Life Domains', Social Indicators Research 82(1): 79-92. http://dx.doi.org/10.1007/s11205-006-9015-0

Roets, A., A. V. Hiel, and I. Cornelis (2006) 'Does materialism predict racism? materialism as a distinctive social attitude and a predictor of prejudice', European Journal of Personality 20(2): 155-168. http://dx.doi.org/10.1002/per.573

Ryan, L. and S. Dziurawiec (2001) 'Materialism and its Relationship to Life Satisfaction', Social Indicators Research 55: 185-197. http://dx.doi.org/10.1023/A:1011002123169

Schulman, J. (2004) 'Introduction', in Your Favorite Seuss: A Baker's Dozen by the One and Only Dr. Seuss, New York: Random House Books for Young Readers, 6-7.

Seuss (1961) The Sneetches and other stories, New York: Random House Books.

Sheldon, K. M., and Kasser, T. (2008) 'Psychological threat and extrinsic goal striving', Motivation and Emotion 32(1): 37.

Simmel, G. (1904/1957) 'Fashion', The American Journal of Sociology 62: 541-558. http://dx.doi.org/10.1086/222102

Srivastava, A., E. A. Locke, and K. M. Bartol (2001) `Money and subjective well-being: It's not the money, it's the motives', Journal of Personality and Social Psychology 80(6): 959-971. http://dx.doi.org/10.1037/0022-3514.80.6.959

Stutzer, A. (2004) 'The role of income aspirations in individual happiness', Journal of Economic Behavior $\mathcal{E}$ Organization 54 (1): 89-109. http://dx.doi.org/10.1016/j.jebo.2003.04.003

Swinyard, W. R., A. K. Kau, and H. Y. Phua (2001) Happiness, Materialism, and Religious Experience in the US and Singapore, Journal of Happiness Studies 2(1): 13-32.

http://dx.doi.org/10.1023/A:1011596515474

Twitchell, J. B. (1999) 'Two Cheers for Materialism', The Wilson Quarterly 23(2): 16-26.

Veblen, T. (1899/1965) The Theory of the Leisure Class, A. M. Kelley, bookseller, NY.

Wang, Jeff, and M. Wallendorf. (2006) 'Materialism, status signaling, and product satisfaction', Journal of the Academy of Marketing Science 34: 494-505. http://dx.doi.org/10.1177/0092070306289291

Warr, P. (1999) Well-Being and the Workplace, in D. Kahneman, E. Diener, \& N. Schwarz, eds., WellBeing: The Foundations of Hedonic Psychology. New York: Russell Sage Foundation, 392-412.

Wilson, T. D., and D. T. Gilbert (2003) Affective Forecasting. In M. P. Zanna, ed., Advances in Experimental Social Psychology 35: 345-411. New York: Academic Press.

Wright, N. D. and V. Larsen (1993) 'Materialism and Life Satisfaction: A Meta-Analysis', Journal of Consumer Satisfaction, Dissatisfaction, and Complaining Behavior 6: 158-165. 